\title{
Social Representations of the Wheelchair for People with Spinal Cord Injury ${ }^{1}$
}

\author{
Viviane de Souza Pinho Costa ${ }^{2}$ \\ Marcia Regina Antonietto Costa Melo ${ }^{3}$ \\ Mara Lúcia Garanhani ${ }^{4}$ \\ Dirce Shizuko Fujisawa ${ }^{5}$
}

In seeking to understand the social representation of the use of the wheelchair through the analysis of interviews with ten people who have suffered spinal cord injury, the construction of five representations was elaborated. The phenomenon experienced regarding the wheelchair provided a route of meanings and symbologies: essential equipment, after the person perceive the inability to walk; a symbol of disability when the person experienced functional dependence; means of locomotion and transport after the rescue of their potential functional; becoming an integral part or all of their body and, finally, the concept of autonomy on four wheels by adjusting to their new ability to walk emerges. The wheelchair as an extension of the modified body for spinal cord injury, returns them the right of locomotion, presents them not only with autonomy for various acts of life, but also restores their dignity, so essential to human life.

Descriptors: Spinal Cord Injuries; Wheelchairs; Disable Persons; Locomotion.

\footnotetext{
${ }^{1}$ Paper extracted from Doctoral Dissertation "Representações sociais da cadeira de rodas na lesão da medula espinhal: de equipamento indispensável à expressão de autonomia" presented to Escola de Enfermagem de Ribeirão Preto, Universidade de São Paulo, WHO Collaborating Centre for Nursing Research Development, SP, Brazil.

2 Physical Therapist, Doctoral Student in Nursing, Escola de Enfermagem de Ribeirão Preto, Universidade de São Paulo, SP, Brazil. Professor, Universidade Norte do Paraná, PR, Brazil. E-mail: viviane.costa@sercomtel.com.br.

${ }^{3}$ RN, Ph.D. in Nursing, Professor, Escola de Enfermagem de Ribeirão Preto, Universidade de São Paulo, SP, Brazil. E-mail: mracmelo@eerp.usp.br.

${ }^{4}$ RN, Ph.D. in Nursing, Associate Professor, Universidade Estadual de Londrina, PR, Brazil. E-mail: maragara@dilk.com.br.

${ }^{5}$ Physical Therapist, Ph.D. in Education, Adjunct Professor, Universidade Estadual de Londrina, PR, Brazil. E-mail: dirce07@sercomtel.com.br.
}

Corresponding Author:

Viviane de Souza Pinho Costa

Universidade Norte do Paraná - UNOPAR

Coordenação do Curso de Fisioterapia - sala 808

Avenida Paris, 675

Jardim Piza

CEP: 86041-120 Londrina, PR, Brasil

E-mail: viviane.pinho@unopar.br 


\section{Representações sociais da cadeira de rodas para a pessoa com lesão da medula espinhal}

Na busca por compreender a representação social do uso da cadeira de rodas, através da análise de entrevistas com dez pessoas que sofreram lesão da medula espinhal, elaborou-se a construção de cinco representações. O fenômeno vivenciado sobre a cadeira de rodas possibilitou uma trajetória de significados e simbologias: equipamento indispensável, após a pessoa perceber a incapacidade para andar, símbolo de deficiência quando vivencia a dependência funcional; meio de locomoção e transporte após o resgate de seus potenciais funcionais, passa a integralizar parte ou todo o seu corpo e, por fim, emerge a concepção de autonomia sob quatro rodas, pela adaptação à sua nova capacidade de locomoção. A cadeira de rodas, como extensão do corpo modificado pela lesão medular, ao devolver-lhe o direito de locomoção, presenteia-o não só com a autonomia para vários atos da vida, como the devolve a dignidade, tão essencial à vida humana.

Descritores: Traumatismos da Medula Espinhal; Cadeiras de Rodas; Pessoas com Deficiência; Locomoção.

\section{Representaciones sociales de la silla de ruedas para la persona con lesión de la médula espinal}

Buscando comprender la representación social del uso de la silla de ruedas a través del análisis de entrevistas con diez personas que sufrieron lesión de la médula espinal, elaboramos la construcción de cinco representaciones. El fenómeno experimentado sobre la silla de ruedas posibilitó una trayectoria de significados y simbologías: es un equipamiento indispensable, después de la persona percibir la incapacidad para andar; es símbolo de deficiencia, cuando siente la dependencia funcional; es un medio de locomoción y transporte, después del rescate de sus potenciales funcionales; pasa a integrar parte de su cuerpo; y por último, emerge la concepción de autonomía bajo cuatro ruedas, al adaptarse a su nueva capacidad de locomoción. La silla de ruedas como extensión del cuerpo modificado por la lesión medular, al devolverle el derecho de locomoción, le ofrece autonomía para varios actos de la vida y le devuelve la dignidad, tan esencial a la vida humana.

Descriptores: Traumatismos de la Médula Espinal; Silla de Ruedas; Personas con Discapacidad; Locomoción.

\section{Introduction}

Spinal cord injury (SCI) results in significant disabling and permanent clinical manifestations, such as the inability to walk, generated by partial or total failure of the functioning of the spinal cord, resulting from an injury that affects the anatomical integrity. The bodily changes and limitations of functional actions, relevant to the deficiency state, provoke diverse social and psychological responses in the personality of the person affected by the $\mathrm{SCI}^{(1-3)}$.

The social representation (SR) and personal representation of the disability is a sort of lens through which the individual is seen and sees his world. These perceptions can be rife with stereotypes and prejudices on both sides, as the individual is a social being, participating in the construction and maintenance of concepts, status and values of society(3).

The need of a wheelchair increases the symbolic arsenal of the condition of disability that the person, affected by the SCI, faces. It expresses the characteristics of functional disabilities and disadvantages that people can present facing physical, sensory and psychosocial 
aspects, reinforcing segregation and discriminatory feelings from society.

The importance of studying the SR to approach information pertinent to the feelings involved in the use of a wheelchair brings together the concept (signified) and the object (the signifier). The intimacy between subject and represented object is also expressed in the understanding that the subject will have of the object from his personal experiences and previous social-group interactions. Thus, each person is surrounded, both individually and collectively, by words, ideas and images that promote the experienced concepts of the object, without even realizing this ${ }^{(4)}$.

The concern of how the wheelchair will be introduced for the person with SCI, is not widespread in the area of neurological rehabilitation and is directly related to experienced psychosocial reactions facing the sudden impact of the various clinical manifestations, leading to the new condition of limitations imposed on their new body.

Faced with reflections on the marked process of the suffering care of people with SCI, this approach will not only be important for professional physiotherapists, but for the whole health care team assisting this patient, to meet the expectations of minimizing some of their suffering faced with all the changes that occur after the injury. Some prospects for overcoming these are the prioritizing of an effective preparation of professional and material resources as a form of technical and institutional support, preferably linked to public policies aimed at fulfilling such complex demands of the binomial caregiver-disabled person, considering all the psychological, social and cultural specifics presented here ${ }^{(5)}$.

This situation, relevant to the rehabilitation process, led to the search for understanding of the social representation of the use of the wheelchair assigned by people with SCI.

\section{Methodology}

This was a qualitative, descriptive study, based on the theoretical framework of social representations, for understanding the phenomenon of the representation of the wheelchair assigned by people with SCI. The importance of this choice is highlighted by the valorization of popular knowledge, to understand the representation of a social object, through the interaction of a particular group of people with paraplegia, through the content expressed in the information, images, opinions and attitudes, as a function of the psychosocial and cultural context experienced by the participants. The representation exists in the space between the perception and the concept and its character of image. It is a concrete mental content of an act of thought which symbolically restores something missing and, by their formulated concepts which propose an interface between individual and collective phenomena, in a psychosocial approach, through the SR, as a means of thinking about subjectivity in the Social Sciences ${ }^{(5-7)}$.

For the collection of information, after adjustments arising from pilot interviews, semi-structured interview from six guiding questions were used, which broadly covered the subject matter. These were recorded on a digital recorder and transcribed, to allow the moment of speech to be replayed with all its particularities. For the analysis of the obtained information, we use the Content Analysis technique, by carrying out text analysis, through extensive reading and listening to the recordings for the thematic approach of their interpretation ${ }^{(8)}$.

The established scenario was two specialist care services for people with neurological damage due to SCI in the city of Londrina in Paraná state, one being public and the other private. The study sample, based on the criteria of saturation sampling, consisted of five people of each care service, after achieving an understanding of the homogeneity, diversity and intensity of information necessary for the study ${ }^{(9)}$.

The interviews took place at the sites of physiotherapy care of each participant, respecting their criterion of day and time availability. They took place inside private, quiet environments, without interruption from other people, so we could ensure privacy, spontaneity and confidentiality of information collected. There was also the application of a questionnaire for the characterization of the participants in relation to identification, their clinical condition and wheelchair equipment.

Inclusion characteristics of the participants were: over the age of majority; both sexes; diagnosed with SCI established by the paraplegia with the sensory and motor segment injured from T2; present themselves in the chronic phase with three or more years of diagnosis substantiated by prolonged use the wheelchair and defined as the most widely used means of locomotion and agree to participate voluntarily in this study, after having signed the free prior informed consent form approved by the Ethics Committee conforming to Resolution CNS 196/96. 


\section{Results and Discussion}

The analysis of the characterization of the participants showed a population consisting of six men and four women, with a mean age of 44.3 years $(S D=12.5)$. The marital status was balanced between married and unmarried. Of the participants, $40 \%$ had two children, $30 \%$ one child, and the other $30 \%$ had no children. Regarding the work situation, seven participants maintain employment contracts and the others did not carry out any set professional activity, only one participant carried out domestic activities without payment.

The mean family income was 5.3 times the minimum wage, with $80 \%$ living in their own property, adapted for the use of a wheelchair and without architectural barriers. As for driving, six people had their own cars adapted for driving according to their disability, two nonadapted cars and the other two were users of special collective transportation.

The more common height of spinal cord injury was the twelfth thoracic segment (T12), in 40\% of participants. The sensory and motor functional classification was ASIA B in $80 \%$. Concerning the etiology of the SCI, the predominant cause was car or motorcycle accident, which accounted for $60 \%$ of the cases, and the other $40 \%$ were divided between injury by firearms, being run over, high falls and compression by medullary tumor. The time since injury ranged from 72 to 174 months (median 108 months).

The acquisition of the wheelchair using their own resources was observed in $80 \%$ of participants. The wheelchairs were ideal for the topography of the SCI to the paraplegia, as well as the finding of the presence of all integral components of the model of reference, providing adequate conditions of safety, comfort and functionality for the functional independence of all participants.

Analyses of the interviews from the comprehensive perspective of the SR of the wheelchair allowed the construction of five thematic categories, which, rooted in the psychosocial and cultural reality of the population studied, revealed the following representations: an indispensable piece of equipment; a symbol of disability; means of locomotion and transportation; extension of the lower limbs and body, and expression of autonomy.

We stress that these categories are not necessarily experienced in this sequence or in their entirety by each of them, and not all pass through the five representations described. We can affirm that the representations are part of the phenomenon of being a person with a sequela of SCI, user of a wheelchair, but are not the only ones possible and do not represent a standard for all other studies in the area.

Participants reported the elaboration process and individual transformation from the loss of physical integrity, which led to a change in body image and psychic disintegration from the experience with the injury, culminating in the need to use the wheelchair in their day-to-day routine.

The first thematic category explores the SR of wheelchair equipment as essential and necessary for the continued performance of activities of quotidian life, sometimes, seen as a possibility or utility and sometimes as an "obligation".

We have to accept it as an obligation, because it will take you anywhere, if your arms are strong. [...] The chair is a very good utility in our lives! (P6)

The return to reality after the SCI exposes other feelings related to the fragility and the emotional shock, in the passing of the days experienced with the loss of motor, sensory and autonomic functions, which sets the reaction of denial faced with these implications and the need to use the wheelchair. These factors interfere with the identity and self esteem of the people, due to not having a chance to gradually prepare for the changes that occur, and may lead to miserable feelings. These negative emotional responses, when uncontrolled, can lead to the occurrence of a state of depression in these people ${ }^{(10)}$.

Terrible! I felt like, the lowest of the people. Useless at everything! (P1)

At that moment, the surprise, it is as if someone gave you news of the death of someone you love very much! So that pain, you're astonished at the time, you don't believe it! It is something without explanation! Then, the reaction was! Ah! I want to die! I have died! There's nothing more. Finished. You can no longer accept. That image of the chair comes in your head and you cannot accept. It is, perhaps, I think maybe worse than death! I do not know! There are feelings. It's very confusing! But the image of the chair at first when you receive the news is terrible! It's like you..., died, my God! Where am I? You cannot imagine anything good. Nothing, absolutely nothing! You, do not have much explanation! It is a mixture of feelings, many bad feelings! You are unable to see anything good! Absolutely nothing. (P7)

The loss of motor, sensory, physiological, psychoemotional, social and structural functions generates, in sequence to the care from health professionals, the intervention of new caregivers who will work during the discharge phase and in their homes. Of all participants, 
six of them referred to the family as the main support to overcome the anguish experienced by the changes in their lives and the aid in the restructuring of this new perspective $^{(5)}$.

Living in a bed, receiving nourishment, food, water, all by the hand of others, doing all the physiological needs in a bed, the others having to carry out hygiene, because I could do nothing, I just moved my eyes, could not stop, I had no strength in my body, had no balance, I fell from one side to the other and so they bound me and there I sat. (P4)

The guidance and early monitoring of patients by caregivers are important factors that facilitate a satisfactory adaptation to daily activities, through the exchange of knowledge about the relationships that are established, develop and reorganize themselves between caregiver and patient ${ }^{(5)}$.

The wheelchair as evidenced by the participants, at this first moment, represents an indispensable piece of equipment. At this stage, a condition of personal conflict starts to configure in the acceptance faced with the need to use this equipment as a result of organic changes caused by spinal cord injury. At the same time, it sets up the possibility to get out of the hospital or home bed after the incident, and enables the change of the constraint condition that the person encounters due to the impossibility of locomotion.

The second category covers the statements that characterize aspects of health and illness of people affected by SCI, who start to live and perceive the changes of their organic, psychological and social functions, exteriorizing a pathological state that represents a form of "disability".

The disability, especially in this sphere, faces a totally exclusionary society, in which the presence of a body that exposes the error of changes in their parts, according to the valuation of symbolic or classificatory criteria current in this society, can create different representations of this body to the human condition. Under this view, we must fight with the intention of constructing an inclusive society, receiving disabled people, already shaken by their losses suffered, moving away from the current model, where it is them that must adapt to the society.

The relationship with the wheelchair unleashes an unlimited number of feelings and behaviors inherent in human nature. The extent of these feelings occur, from the most basic situations of the difficulties, in order to understand and accept what happened: shock, impact, fear, lack of courage, embarrassment, deep emotional pain, denial of the situation, change in body image, loss of freedom, questioning and belief in the divine, representation of absence of life, suicidal feelings through to some of the statements of hope for a cure and freedom ${ }^{(10)}$.

It's complicated! Very complicated, because we are agile in everything, then suddenly we are imprisoned in the chair, then ehhhh, there are times that we enter into ... we will not say panic, but a lot of stress. (P1)

The feeling of shame and inferiority appears due to the inability to walk after the injury, and these body changes culminate in the perception of being satirized by the population when displaying their current image, conferring the presence of stigma on their disability. Studies say that from this stigma, people with disabilities understand their body as an object of shame, while experimenting with disabilities in relation to the current standard of productivity in society ${ }^{(11)}$.

I was ashamed, of being me that person that walked and of seeing myself in a wheelchair. I thought the others would make fun, I thought that others would ridicule me to my face. So I thought this, I imagined this kind of thing. (P4)

Another important constraint factor for people with disabilities is due to the preconceptions of individuals as well as historical and cultural aspects. This is a social phenomenon, but also with personal manifestations, which may lead to feelings of low self-esteem, difficulties in affective and social relationships, prejudicing the quality of life of people with SCI. The way this person is "seen" is changed according to social, moral, philosophical, ethical and religious values adopted by different cultures in different historical moments. Thus, the preconceptions related to disability, though they often appear in a different configuration, still occur in modern times ${ }^{(12)}$.

[...] Damn! The guy is in a wheelchair, the guy is lame! (P4)

Look, sincerely, I think that not only are we unprepared, but the people are also not prepared to receive us. The look is different, you know! Either are we treated as pitied, or ignored! (P10)

The wheelchair equipment has a clear SR of disability. This, often expressed by society in its broadest definition, includes aspects of mental disorders in people who have only motor deficits due to spinal cord injury, classified as disabled. The wheelchair can present itself as stigma associated with functional dependency, with prejudice, with futility of the human being, and with mental and cognitive deficits.

There are times that the person doesn't address you when they have to ask you something, they do not ask the person in a wheelchair, they ask the person who is with them. So, there 
is much that the person has to learn, that a person in the chair, doesn't always have a problem, let us assume, of the head, shall we say, mental, and, just because they are a paraplegic. (P1)

The condition of disability excessively increases the difference in the eyes of society, whereby the bodily presentation highlights the difference between the whole and the fragmented, between the perfect and the imperfect, and highlights the association with a device like the wheelchair. The historical and cultural influences, to this day, remain fraught with stigma and prejudicial values, concerning the body modified by chronic diseases such as those involved with SCI. In this aspect the wheelchair maintains the body alterations and reinforces the stigmatizing characteristics, such as the SR of the disability. It may also represent, at some point of the rehabilitation process, the transition to a more independent life through daily contact with this equipment.

The third category relates to the means of locomotion and transport that the wheelchair can be for people with paraplegia. The statements of the participants expressed the significance of a means of locomotion and as a means of transport, in a firm and clear manner, defining the wheelchair as the new way to return to walking on "four wheels" faced with the permanent motor loss caused by the spinal cord injury.

The meaning, as I told you! You move. The goal of the chair today is this, it is to be able to use it, where you can go, and you do what you can do with it. And it is to move, to do everything! (P6)

The possibility of allowing freedom of movement, even on wheels, turns the wheelchair into a device that can also facilitate the reorganization of basic and even the most complex functional activities. It allows the enjoyment of social, educational, vocational and recreational opportunities, driving the person toward social integration and into a productive and rewarding lifestyle.

[...] I am happier today sitting in a wheelchair than when I walked. It's comfort! I have my chair. And it is a utility in our lives today! It is appropriate for us to work, do some things for us to move from one place to another. (P6)

However, there is a path followed to build the representation of locomotion and transportation, therefore, before ensuring these skills independently, the wheelchair user faces many difficulties such as plegia of the trunk and lower limb muscles, loss of trunk control in sitting posture and lack of balance, being the changes related to paraplegia. The initial experience can lead to feelings of fear, due to the instability of a wheelchair in motion, for example, the comparison with cycling for the first time(13).
The first rides are bad, because one has to get the balance like on the bicycle, so it goes to the stomach, really I fell along with the chair, because I did not know, I had no practice, right! I went backward one day, the first time there in my sister's house, I fell because I did it with a lot of strength, I didn't have balance yet, I was kind of stuck, off balance, then, I went backwards all in one go. (P8)

The better the quality of the wheelchair, the easier to steer it and to surmount the architectural barriers, found in most environments frequented by all of us, resulting in greater success in functional performance ${ }^{(13)}$.

And to have a good chair too, to move in the city there, it has to be good. Because there are many holes, too many stones in the street, a lot of things, if the chair is not $100 \%$ you fall! It's easy, every pebble overturns us, and to get up is a difficulty! But we go living the life! (P3)

In this phase, during the rehabilitation process and daily contact between the user and equipment, it will progressively enable mobility with independence in locomotion. The profile of the feelings that emerge in people with SCI presents itself as positive characteristics of well-being with the condition of adaptation to disability, with a noticeable improvement in self-esteem and also the perception that the wheelchair no longer represents a stigma or something that generates prejudice, but represents their means of locomotion and transport, along with the benefits that come with independence.

The construction of the category of social representation of the wheelchair as a part or full extension of the body of people with SCI, demonstrates the overcoming of the feelings of prejudice and stigma in the face of changes that occurred in their body and the use the wheelchair. At this time, people demonstrate in their statements the opposition of the SR of the symbol of disability and show their perspective on life in a healthy way and feelings of happiness for their affinity with the wheelchair.

Same thing as having legs, because without the wheelchair the guy is going nowhere, has to stay sitting in a place without moving, how is he going to walk he does not have a way, with the chair the force goes into the arm and the arm pushes the body, then away it goes, calm, I think! If you take this wheelchair from me this is the same as cutting off my legs. (P10)

For some participants, this perception occurs in the initial stage of their involvement, with the visibility of association of the wheelchair as an extension of their lower limbs paralyzed by the SCI, as the ability to walk again, to move themselves. What seemed to be a merely useful and necessary piece of equipment becomes indispensable and essential in their lives, a part of their bodies. 
I was in the hospital, they taught me to get out of the bed into the chair, to take a ride, because that there was to be my legs. The wheelchair, when I rode it, it didn't mean anything, but now it is my life, it is my legs, and a lot of times, we comment at home: wow! The wheelchair is a burden! Then I correct my children again, because if it is a burden, I would not walk, how would I walk? So it is essential in my life, there today! Today it is my legs. (P3)

The reports analyzed by other studies also resulted in the idea that the wheelchair has become an extension of the body of its users in an inextricable way and as a new reality of life(14).

The social representation of the wheelchair as a part or an extension of the body passes from the condition of a concrete complement of the body part to the condition of the body itself, i.e. the person no longer distinguishes the division between body and chair. The simple fact of not sitting in the chair promotes a sense of bodily loss, in contrast with the feeling of bodily integrality when seated in the wheelchair(14).

[...] When I sit on the sofa, it is where I miss my legs, in the chair I do not feel this [...] So, I like the chair, it is a part of my body, understand? When I go to sleep I lay in bed and it is right there, you know? This would be, sometimes, there are people (laughs) that have a pet dog, where they go the dog goes behind. And me, it is my chair, where I go I'm with it, and when I'm not with it, it is at my side (laughs). My wife is also most of the time, but not always, but the chair! [...] It is at my side more than anything else, then, it is something like this, you know, it is where I am, I'm with it. [...] Yes, it's safety, all these things, you know, I feel more like you say, complete! (Laughs) I feel myself as half a man, and with the chair I can feel myself as a whole man (laughs) and I still play as if the chair speaks (laughs). (P9)

The body has a social function and figure in the cultural order, derived from social meanings and symbols. Given the importance attached to the body in our society, we can scale the effect in the relationship with the others that the disabled person is submitted, as they are continually confronted with the failure of some assumptions concerning the ideals relative to embodiment. So, the intervention of culture on the body, according to the assumptions of social inclusion, could focus on the aesthetic standards, on the conception of beauty, but especially on the way that disabled individuals are viewed and perceived in society. These changes will reflect in the image they have of themselves, as a result of this social relationship, and also in the current ways of living and conceiving the body with the interaction with the wheelchair(2).
The fifth and final category configures the SR of the wheelchair as an expression of autonomy, in which, within the context studied, the participant has reached the highest level of biopsychosocial independence and is able to participate in and demand from society the right to social inclusion.

[...] because without the wheelchair I do not walk, I stay without moving vegetating in a bed, on a sofa, in whatever chair, and with the wheelchair I have that autonomy to come and go where I want to, I just need the arms help. (P3)

The wheelchair is presented as facilitating the body mobility, which allows freedom of movement of part of or the whole body and principally the capacity to come and go, to or from anywhere, by persons with disabilities, as a real expression of autonomy. It composes an important instrument to provide functional independence, strengthening the search for personal autonomy.

I do not come to the center by pushing it because it's too far, but I catch the bus, I get off the bus, I go, suffer a bit with those bad sidewalks they have there, but we can move well in the city, go to where we need to go [...] (P8)

To experience and achieve the process of elaboration of the indispensable equipment being transformed into autonomy, allows the individual to re-signify their existence and causes them to perceive new possibilities, make choices, set goals and create their own future. The evolution to the condition of adaptation of people with SCI can generate invaluable gains, since it enables them to recognize their potential to, subsequently, participate in society in an active and self-determined way. Moreover, it promotes the transformation of society itself, as it allows the opportunity to actually see the person with a SCI according to their limitations, their values and their functional potentials. This could open an important space in our society: a space for human diversity, as independent and autonomous beings. These conditions rescue their self-esteem, the enjoyment of life, becoming triggering elements in the constant search for overcoming the difficulties, having as a consequence, an improvement in the quality of life.

\section{Final considerations}

The statements reported in this study showed the experiences of people that, from the involvement of the $\mathrm{SCI}$, are now living with a life of quotidian elaborations and changes pertinent to the changes in their bodies. 
New concepts and meanings are being constructed in the conceptions of these disabled people, represented by popular knowledge, based on their quotidian experience with the use of a wheelchair. The categories formulated are characterized by an upward trend of coexistence between the clinical manifestations and use of a wheelchair, associated with the support of family and psychosocial and cultural aspects.

It is necessary to establish the relationship between health professional and patient from their entrance into the hospital and to establish the presence of their families, based on the professional ethical principles, trust and humanity, so that information about their new status as a result of the SCI and the use of a wheelchair are given in a direct, realistic and warm way, in order to minimize the confrontation with the clinical manifestations that will come.
Furthermore, it is necessary that the public policies of attention to people with disabilities are constantly improved by governmental organizations, as well as there being effective compliance of supervision by society in general, in order to minimize social differences, prejudice and discrimination. This focus of public policy attention to people with disabilities strengthens the practice of the concept of social inclusion, since the law tends to equate the rights, duties and values among citizens in all instances, and allows these people to assume their roles of personal autonomy in society, regardless of the use of a wheelchair.

In this context the wheelchair as an extension of the body modified by spinal cord injury, when returning to the person the right of locomotion, not only presents them with autonomy for various acts in life, but also gives them back their dignity, so essential to human life.

\section{References}

1. Pereira MEMSM, Araújo TCCF. Estratégias de enfrentamento na reabilitação do traumatismo raquimedular. Arq Neuro-psiquiatr. 2005 junho; 63(2-B):502-7.

2. Chau L, Hegedus L, Praamsma M, Smith K, Tsukada M, Yoshida $\mathrm{K}$, et al. Women living with a spinal cord injury: perceptions about their chanced bodies. Qual. Health Res. 2008 February; 18(2):209-11.

3. Fechio MB, Pacheco KMB, Kaihami HN, Alves VLR. A repercussão da lesão medular na identidade do sujeito. Acta Fisiátrica. 2009; 1(16):38-42.

4. Martini JG, Furegato ARF. Teachers' social representations on drug use in a secondary school. Rev. Latino-Am. Enfermagem. julho/agosto2008; 16(spe):601-6.

5. Azevedo GR de, Santos VLC de G. (Handicapped) Caregiver: the social representations of family members about the caregiving process. Rev. Latino-Am. Enfermagem. outubro2006; 14(5):770-80.

6. Jodelet D. The body and his transformation. In: Farr S, Moscovici S, editors. Social representation. Cambridge: Cambridge University Press; 1984.

7. Jodelet D. Representações sociais: investigações em psicologia social. 3a ed. Petrópolis (RJ): Vozes; 2003.
8. Bardin L. Análise de conteúdo. 4a ed. Lisboa: Edições 70; 2007.

9. Fontanella BJB, Ricas J, Turato ER. Amostragem por saturação em pesquisas qualitativas em saúde: contribuições teóricas. Cad Saúde Pública janeiro2008; 24(1):17-27.

10. Murta SG, Guimarães SS. Enfrentamento à lesão medular traumática. Estud. Psicol. 2007; 12(1):57-63.

11. Rocha EF. Corpo deficiente em busca da reabilitação? Uma reflexão a partir da ótica das pessoas portadoras de deficiência física [dissertação de mestrado]. São Paulo (SP): Universidade de São Paulo. Instituto de Psicologia; 1991.

12. Pacheco KMB, Alves VLR. A história da deficiência, da marginalização à inclusão social: uma mudança de paradigma. Acta Fisiátrica. 2007; 4(14):242-8.

13. Lianza S, Casalis MEP, Greve JMD, Eichberg, R. A lesão Medular. In: Lianza S, editor. Medicina de Reabilitação. 3 ed. São Paulo: Manole; 2001. p. 299-322.

14. Garanhani MR, Fujisawa DS, Capelli AMG, Ribeiro MC, Garanhani ML. A cadeira de rodas para o indivíduo com lesão medular: o equipamento, a utilização e o significado. In: Manzini EJ. Inclusão do aluno na escola: os desafios continuam. Marília: ABPEE/FAPESP; 2007. 256 p.

Received: Jul. 6th 2009

Accepted: Jan. 14th 2010 